\title{
Editorial
}

\section{Introduction: Ghost H(a)unts}

Agata Handley, ${ }^{1, *}$ Ceri Morgan ${ }^{2}$ and Vanja Polić ${ }^{3}$

How to cite: Handley, A., Morgan, C., and Polić, V. 'Introduction: Ghost H(a)unts.' London Journal of Canadian Studies, 2018, 33(1), pp. 1-4. DOI: https://doi.org /10.14324/111.444.1jcs.2018v33.001.

Published: 14 November 2018

\section{Peer Review:}

This article has been peer reviewed through the journal's standard double-blind peer-review, where both the reviewers and authors are anonymized during review.

\section{Copyright:}

(c) 2018, The Author(s). This is an Open Access article distributed under the terms of the Creative Commons Attribution License (CC-BY) 4.0 https://creativecommons.org/licenses/by/4.0/, which permits unrestricted use, distribution and reproduction in any medium, provided the original author and source are credited $\bullet$ DOI: https://doi.org/10.14324/111.444.ljcs.2018v33.001.

\section{Open Access:}

London Journal of Canadian Studies is a peer-reviewed open access journal.

\footnotetext{
*Correspondence: agatagrazyna@gmail.com

${ }^{1}$ University of Lodz, Poland

${ }^{2}$ Keele University, UK

${ }^{3}$ University of Zagreb, Croatia
} 


\title{
Introduction: Ghost $\mathrm{H}(\mathrm{a})$ unts
}

\author{
Agata Handley, Ceri Morgan and Vanja Polić
}

Ghosts come in a variety of guises. They serve to unsettle the present, reminding us of unfinished business from the past. They also comfort, recalling loved ones who are no longer with us. They can gesture towards those who are yet to be born if, along with Jacques Derrida, we accept that ghosts disrupt chronological time. ${ }^{1}$ In all cases, however, ghosts are characterized by a play between absence and presence, self and other, silence and speech. As Susan Bruce argues, 'absence [is] the paradoxical evidence of the ghost's existence'. ${ }^{2}$ Ghosts do not necessarily assume human form: animals are not very present in this issue, but places certainly are. The concept of place as made up of layers formed over time and which bleed into each other, as found in Walter Benjamin's The Arcades Project, ${ }^{3}$ is taken up by many critics and creative practitioners. ${ }^{4}$ In what follows, cities, villages, islands and continents shimmer in and out of view, as do loved ones, lost ones and ones who resist being forgotten even though their actions suggest they should be.

In her book on spectrality in contemporary women's writing, Martine Delvaux describes Derrida as undertaking a 'ghost hunt' in Marx's work. ${ }^{5}$ The articles in this issue engage in a similar exercise. Agata Handley's article focuses on the struggle of dealing with loss and re-living the past in Jane Urquhart's The Stone Carvers (2001). Referring to the concept of the death mask and the classical topoi of nekuia and katabasis, Handley discusses the way in which the theme of haunting is interwoven by Urquhart into a larger narrative, forming an ongoing meditation on the migrant experience, traumatic memory and artistic endeavor, while reflecting the transience of human existence. As its name suggests, Amy Coquaz's critical-creative 'Writing absence: troubled and troubling texts' centers on questions around absence: in the first instance, the absent 
fathers in Delvaux's Governor-General's Award shortlisted novel, Blanc dehors (2015) and her own forthcoming novel, Toi. These ghostly paternal figures go on to become prompts for exploring what it means to write absence and, ultimately, stimuli for writing itself. Doubling - of self, of voice, of language, of fact and fiction - works as a haunting which deliberately seeks to trouble and disturb by challenging homogeneity and normativity. Coquaz claims, 'it is a long-understood principle of creative writers that what is not said is as important as what is said' (page 23). Ceri Morgan's 'Sonic spectres' analyses the different kinds of haunting and their connections with the said and unsaid in Madeleine Thien's Dogs at the Perimeter (2011) and the digital map she produced with media artist, Philip Lichti entitled 'Fictional Montreal/Montréal fictif' (2016-17). Reflecting on the ways in which both novel and map play around absence and presence, Morgan argues that they embrace the potentially utopian aspect of spectrality identified by Derrida. ${ }^{6}$

Sound also features in Evelyn Deshane's and Travis Morton's 'The Words Change Everything: Haunting, Contagion and the Stranger in Pontypool' (1998). Using Bruce McDonald's 2008 film as a case study for exploring issues around contagion - notably linguistic contagion Deshane and Morton argue that it challenges some of the genre conventions of the zombie movie. Claiming that Pontypool effects a shift in focus from 'invasion' associated with spectacular gore, to 'haunting' (page 23) as expressed through language, the authors suggest that it has the potential to promote linguistic and gender inclusivity. Questions of genre come into play in Vanja Polić's 'The Hauntings of Canada in Michael Crummey's Sweetland' (2014). Viewing Crummey's novel through the lens of the gothic, Polic draws attention to the ways in which it challenges conceptualizations of Canadian national identity - and, indeed, national identities in general - by insisting on the significance of the local. Jasmina Bolfek-Radovani examines the notion of 'postcolonial hauntings', and their role in the construction of the language of memory, in two narratives by francophone authors of mixed background: Robert Lalonde's Sept Lacs plus au Nord (1993) and Nina Bouraoui's Mes mauvaises pensées (2005). Applying a method of a close textual reading, Bolfek-Radovani investigates different aspects of the postcolonial framework, including but not limited to the notions of postcolonial ambiguity; the re-appropriation of native space; and the idea of the moment of 'stillness' as a resurgence of memory.

Several of the articles were first given as papers at the British Association for Canadian Studies conference in London in April 2017 as part of a special panel entitled 'Absent presence/present absence: hauntings 
in Québécois and Canadian literature and film'. As the UK prepares to leave the European Union, it is, perhaps, a timely moment to think about a project undertaken by colleagues in Croatia, Poland and the UK as itself a kind of ghost - of international cooperation, collaboration and friendship across disciplines and languages.

\section{Notes}

1 Jacques Derrida, Spectres de Marx: L'État de la dette, le travail du deuil et la nouvelle Internationale (Paris: Galilée, 1993), 72.

2 Susan Bruce, 'Sympathy For the Dead: (G)hosts, Hostilities and Mediums in Alejandro Amenàbar's The Others and Postmortem Photography', Discourse, 27.2 \& 27.3 (Spring and Fall 2005): 22 .

3 Walter Benjamin, The Arcades Project, trans. Howard Eiland and Kevin McLaughlin (London: The Belknap Press, 2002).
4 See, for example, Robert E. Macfarlane, The Old Ways: A Journey on Foot, (London: Hamish Hamilton, 2012), Will Self, Psychogeography (London: Bloomsbury, 2007).

5 Martine Delvaux, 'Hanté par la figure de Hamlet, Derrida part à la chasse aux fantômes dans l'œuvre de Marx', Histoires de fantômes. Spectralité et témoignage dans les récits de femmes contemporains (Montréal: les Presses de l'Université de Montréal, 2005), 17.

6 Derrida, Spectres de Marx, 71.

\section{Bibliography}

Benjamin, Walter. The Arcades Project, trans. Howard Eiland and Kevin McLaughlin (London: The Belknap Press, 2002).

Bruce, Susan. 'Sympathy for the Dead: (G)hosts, Hostilities and Mediums in Alejandro Amenàbar's The Others and Postmortem Photography,' Discourse 27.2 \& 27.3 (Spring and Fall, 2005).

Delvaux, Martine. Histoires de fantômes. Spectralité et témoignage dans les récits de femmes contemporains (Montréal: les Presses de l'Université de Montréal, 2005).

Derrida, Jacques. Spectres de Marx: L'État de la dette, le travail du deuil et la nouvelle Internationale (Paris: Galilée, 1993).

Macfarlane, Robert E. The Old Ways: A Journey on Foot (London: Hamish Hamilton, 2012).

Self, Will. Psychogeography (London: Bloomsbury, 2007).

\section{Note on Contributors}

Agata Handley is an Assistant Professor in the Faculty of Philology at the University of Łódź, Poland. She completed her PhD in 2014 and is currently continuing her research on contemporary British literature. The main areas of her academic interest are: British poetry, with a special focus on Northern poetry and culture; and contemporary Canadian literature.

She is the author of Constructing Identity: Continuity, Otherness and Revolt in the Poetry of Tony Harrison (2016) which analyzes the theme of 
identity construction recurring in Tony Harrison's work from the 70s onwards. She is a member of the editorial team for Text Matters: A Journal of Literature, Theory and Culture.

Ceri Morgan is a senior lecturer at Keele University, UK. She works on literary geographies in Québec fiction, place writing, walking studies and GeoHumanities. Her publications include Mindscapes of Montreal (2012) and 'Walking studies, the Eastern Townships, and William S. Messier's Dixie', Nottingham French Studies, 55.2 (2016). Her recent projects include a digital map of literary Montréal entitled, 'Fictional Montreal/Montréal fictif' (British Academy small research grant 2016-17), produced with media artist, Philip Lichti; and Seams (2018) - a show about coal mining developed and performed with participatory performance company, Restoke, a walking-writing group at Keele University called the Dawdlers, and community participants.

Vanja Polić is an assistant professor at the Department of English at the University of Zagreb, Croatia, where she teaches literary theory, contemporary Canadian literature and film, and the eighteenth century British novel. She has published articles on Canadian literature and culture in Croatian and international journals, and is the author of a monograph on the rhetorical practices of self-legitimation in the prefatory materials of the early eighteenth century British novel (2012). Her research interests include contemporary Canadian literature, postcolonial literature and postmodernism. Her current project concerns contemporary western Canadian literature, with special emphasis on the revisions of the myth of the West. She is the president of the Croatian-Canadian Academic Society and a member of the editorial board of Canadian Literature.

\section{Conflict of Interests}

The authors declare that there are no conflicts of interests with this work. 